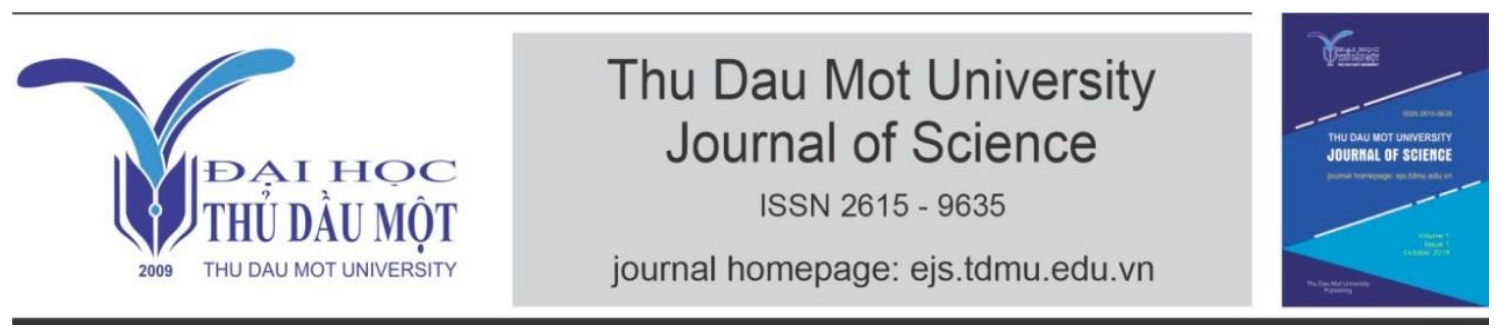

\title{
Building the environmental performance index for industrial parks
}

by Phong Tran, Thuy Nguyen Thi Thanh, Pham Quoc Khanh, Than Nguyen Hien (Thu Dau Mot University)

Article Info: Received April 20 ${ }^{\text {th }}$, 2020,Accepted Aug. 20 ${ }^{\text {th }}$, 2020,Available online Sep. $15^{\text {th }}, 2020$ Corresponding author: thannh@tdmu.edu.vn

https://doi.org/10.37550/tdmu.EJS/2020.03.067

\begin{abstract}
Measuring environmental protection activities is a matter of great concern over the years. In this study, the indicators for evaluating environmental protection activities in industrial parks was built according to the PDSIR model and based on Vietnam's legal framework, including 18 main subjects and 35 indicators. The environmental performance index of industrial park (EPIIP) was established based on the multi-criteria evaluation method and the analytic hierarchy process method. The results of the study indicated that the VSIP I industrial park reached 68.95 points (relatively good level). Moreover, the results also showed that VSIP I was one of the industrial parks practicing good performance to protect environmental problems.
\end{abstract}

Keywords: Environmental performance index, indicators, industrial parks

\section{Introduction}

Economic development is a top priority field of all countries in around the world and economic development associated with environmental protection is increasingly concerned. Sustainable development is indispensable in the context of increasing environmental pollution and climate change. In order to assess the current state of the 
environment in the process of economic and social development, many environmental indicators and indexes have been released in recent years.

In 2005, the environmental sustainability index (ESI) was developed. The ESI is a measuring tool of the progress towards environmental sustainability of each country. The environmental sustainability index was implemented based on 5 main themes, 21 subjects and 76 indicators in related to natural resources, environment, ecology, institutions and society (Yale Center for Environmental Law and Policy \& Center for International Earth Science Information Network, 2005). In 2006, Yale University and Columbia University in the United States published the Environmental Performance Index. The index enclosed 22 indicators representing 10 subject groups towards two main issue groups like environmental health and ecosystem vitality (Daniel Esty et al., 2006). Besides, a range of the studies conducted many environmental assessment indexes as India environmental sustainability index (Institute for Financial Management and Research, 2010), the fuzzy environmental quality index (Roveda. José Arnaldo Frutuoso, Maurício Tavares Mota, Sandra Regina Monteiro Masalskiene Roveda, Roberto Wagner Lourenço, \& Antonio César Germano Martins, 2010), the environment quality index (U.S. Environmental Protection Agency, 2014). These researches were integrated environmental assessment tools for national or local levels that could not be used to assess environmental performance for industrial zones.

In Vietnam in July 2017, the whole country has 328 industrial parks (223 operating) established, accounting for $60-70 \%$ of the total FDI attraction of nation, contributing about $30 \%$ exports of the whole country and created job opportunities for over 2 million workers, contributing significantly to national budget.

In recent years, Vietnam has proclaimed many documents regulating environmental indicators supporting management policy. In 2013, the Prime Minister issued Decision No. 2157 /QD-TTg promulgating indicators for monitoring and evaluating local sustainable development in the 2013 - 2020 period (Prime Minister, 2013). In 2015, the Ministry of Natural Resources and Environment issued Circular No. 35/2015 /TTBTNMT on environmental protection of economic zones, industrial parks and high-tech zones in order to strengthen the legal mechanism to protect the environment in the industrial park (Ministry of Natural Resources and Environment, 2015a). In order to have a legal corridors for environmental assessment and monitoring, the Ministry of Natural Resources and Environment has issued Circular No. 43/2015/TT-BTNMT on the national environmental indicator set and Circular No. 73/2017/TT-BTNMT on the system of natural statistical indicators of resources and environment sector (Ministry of Natural Resources and Environment, 2015b, 2017). However, these indicators has not been able to assess whether environmental protection activities in the industrial zone are good or 
bad, moreover the system of indicators includes many indicators, making it difficult to communicate to the community. In 2018, the Ministry of Construction issued a circular on green growth urban construction targets (Ministry of Construction, 2018). In 2019, the Ministry of Natural Resources and Environment issued Decision No. 2782/QD-BTNMT on October 31 in 2019 promulgating the system of indicators for evaluating environmental protection activities of national center provinces and cities (Ministry of Natural Resources and Environment, 2019). Regarding industrial performance of the provinces and cities, there are currently no guidelines and regulations to evaluate the results of industrial environmental protection activities.

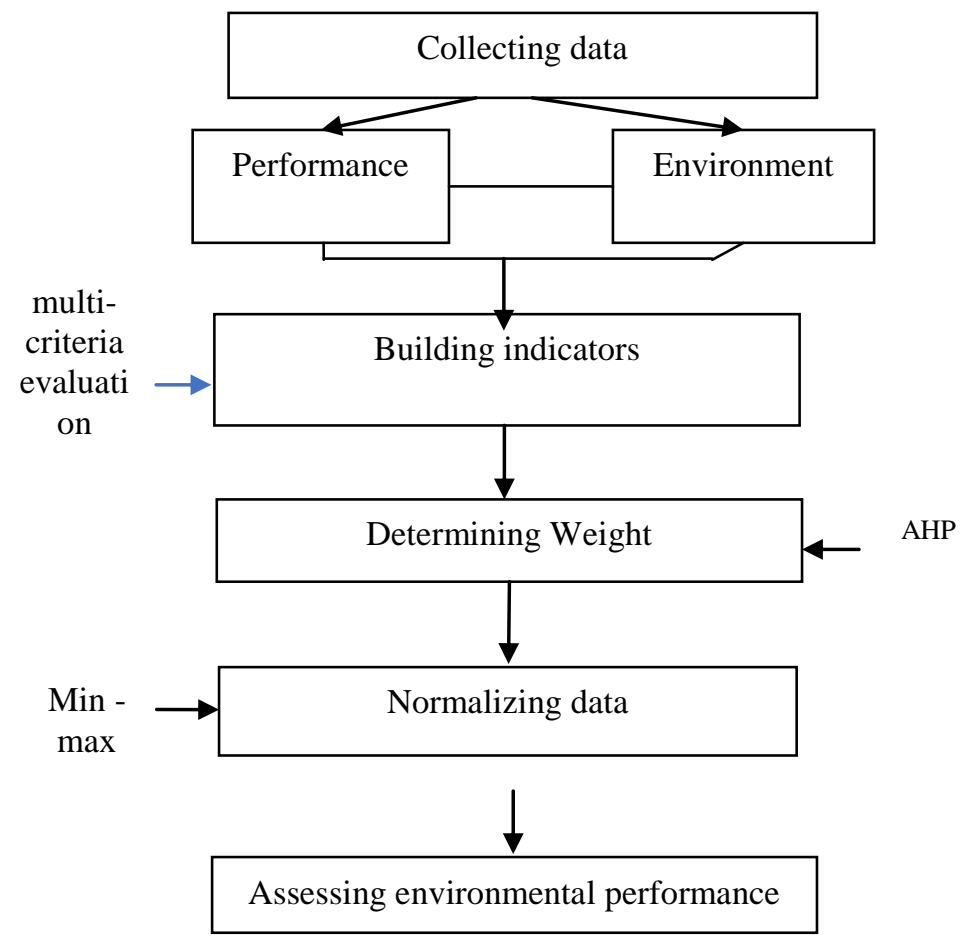

Figure 1. The progress of the study

From the above issues, the development of a indicator system and an index for evaluating the industrial environmental protection activities is very necessary. The study will contribute to the improvement of local environmental protection and support decision-making for environmental management agencies in concentrated industrial areas with the basis for evaluating and raking environmental protection of enterprises.

\section{Materials and methods}

Materials: The research data was collected from the environmental monitoring reports in Industrial Park VSIP I in 2018 and conducted the field surveys. 


\section{Methods}

\section{The Analytic Hierarchy Process (AHP)}

AHP is a semi-quantitative pairing comparison technique based on the method development of Saaty (1995) called hierarchy analysis. The weights for indicators and subjects based on the AHP method is the most optimal method that satisfy both objective and (consistency and statistics) and subjective (human opinions). The weight was determined by comparing to the significance of each indicator on a scale of from 1 to 9 .

TABLE 1. Evaluation values of Saaty in paired comparisons

\begin{tabular}{ll}
\hline \multicolumn{1}{c}{ Comparative value of Saaty } & \multicolumn{1}{c}{ Definition of judgment } \\
\hline 1 & Equal importance \\
3 & Week dominance \\
5 & Strong dominance \\
7 & Demonstrated dominance \\
9 & Absolute dominance \\
$2,4,6,8$ & Intermediate values \\
\hline
\end{tabular}

The evaluation results are expressed in the A matrix of the relationship of the indicators with each other

$$
\mathrm{A}=\left[\begin{array}{cccc}
1 & \mathrm{a}_{12} & \ldots & \mathrm{a}_{1 \mathrm{n}} \\
\frac{1}{\mathrm{a}_{21}} & 1 & \ldots & \mathrm{x}_{2 \mathrm{n}} \\
\vdots & \vdots & \vdots & \vdots \\
\frac{1}{\mathrm{a}_{1 \mathrm{n}}} & \overline{\mathrm{a}}_{2 \mathrm{n}} & \ldots & 1
\end{array}\right]
$$

In order to demonstrate the assessment method, the study was used to 5 topics [drivers, pressures, state, impact, response] for an example. The matrix A of five theme was determined

$$
A=\left[\begin{array}{ccccc}
1 & 1 / 3 & 1 / 2 & 1 / 3 & 1 / 4 \\
3 & 1 & 1 / 2 & 1 / 2 & 1 / 3 \\
2 & 2 & 1 & 3 & 1 / 2 \\
3 & 2 & 1 / 3 & 1 & 1 / 3 \\
4 & 3 & 2 & 3 & 1
\end{array}\right]
$$

The geometric was calculated for each indicators in rows: $\mathrm{m}_{\mathrm{i}}=\prod_{\mathrm{i}=1}^{\mathrm{n}} \mathrm{a}_{\mathrm{ij}}, \overline{\mathrm{w}_{\mathrm{i}}}=\sqrt[n]{\mathrm{m}_{\mathrm{i}}}$ 
$=\left[\begin{array}{l}0.43 \\ 0.76 \\ 1.43 \\ 0.92 \\ 2.35\end{array}\right], \mathrm{w}_{\mathrm{i}}=\overline{\mathrm{w}_{\mathrm{i}}} / \sum_{\mathrm{i}=1}^{\mathrm{n}} \overline{\mathrm{w}_{\mathrm{i}}}$. The weighted vector was obtained as factors: $\mathrm{W}_{11}, \mathrm{~W}_{22}$, $\mathrm{W}_{33}, \ldots \mathrm{W}_{\mathrm{nn}} . \mathrm{W}=(0.07,0.13,0.24,0.16,0.40)=\sum_{j=1}^{n} w_{f}=1$. Then, the confidence of the matrix was implemented to check the consistency of the compared matrix among the indicators. The consistency of matrix A was calculated as follows:

After that, the total weight vector $\mathrm{W}$ for each row to get the vector $\mathrm{B}$ was computed to be obtained B weight matrix of the indicators: $\vec{B}=\sum_{j=1}^{n} \mathrm{a}_{i \mathfrak{i f}}=\left[\begin{array}{l}\boldsymbol{b}_{1} \\ \boldsymbol{b}_{2} \\ \boldsymbol{b}_{n}\end{array}\right]=\left[\begin{array}{l}0.43 \\ 0.76 \\ 1.43 \\ 0.92 \\ 2.35\end{array}\right]$

and each element of vector B was devived by the corresponding element in vector $\mathrm{W}$ $\left(\mathrm{W}_{11}, \mathrm{~W}_{22}, \mathrm{~W}_{33}, \ldots \mathrm{W}_{\mathrm{nn}}\right)$ obtained the vector $\mathrm{c}: \overrightarrow{\boldsymbol{c}}=\left[\begin{array}{c}\frac{\boldsymbol{b}_{1}}{\boldsymbol{w}_{1}} \\ \frac{\boldsymbol{b}_{2}}{\boldsymbol{w}_{2}} \\ \frac{\boldsymbol{b}_{n}}{\boldsymbol{w}_{n}}\end{array}\right]=\left[\begin{array}{c}0.43 / 0.07 \\ 0.76 / 0.13 \\ 1.43 / 0.24 \\ 0.92 / 0.16 \\ 2.35 / 0.40\end{array}\right]=\left[\begin{array}{c}5.38 \\ 5.27 \\ 5.41 \\ 5.39 \\ 5.08\end{array}\right], \lambda_{\max }$ is the mean vector elements c: $\lambda_{\max }=\frac{1}{n} \sum_{j=1}^{n} c_{f}=5.31$. Then, the consistency index appraised by the formula: $\mathrm{CI}=((\max -\mathrm{n}) /(\boldsymbol{n}-\mathbf{1})=0.08$. The consistency ratio $\mathrm{CR}=$ $\mathrm{CI} / \mathrm{RI}=0.08 / 1.12$, if $\mathrm{CR}<0,1$ the pair comparison matrix $\mathrm{A}$ for the indicators was reasonable, otherwise we needed to re- evaluate the pair comparison matrix. In which, $\mathrm{RI}$ is taken according to the table 2 :

TABLE 2. RI scale

\begin{tabular}{cccccccccccccc}
\hline $\mathbf{N}$ & 3 & 4 & 5 & 6 & 7 & 8 & 9 & 10 & 11 & 12 & 13 & 14 & 15 \\
$\mathbf{R I}$ & 0.58 & 0.9 & 1.12 & 1.24 & 1.32 & 1.41 & 1.45 & 1.49 & 1.51 & 1.48 & 1.56 & 1.57 & 1.59 \\
\hline
\end{tabular}

$\mathrm{CR}=0.08 / 1.12=0.07<0.1$. Therefore, the comparison matrix of the subjects in the PDSIR was reasonable and the weights were determined appropriately.

Standardized method 
Data normalization could be done using the following formulas:

$$
\mathrm{I}=\frac{\mathrm{I}_{\mathrm{x}}-\mathrm{I}_{\min }}{\mathrm{I}_{\max }-\mathrm{I}_{\min }}
$$

In which: $I$ is the standardized indicator value, $I_{x}$ is the indicator value, $I_{\min }$ is the minimum indicator value and $\mathrm{I}_{\max }$ is the largest indicator value

Calculating the environmental performance sub-index

The environmental performance index was calculated step by step based on the indicator group. The sub-indicator was calculated using the following formula:

$$
\mathrm{I}_{\mathrm{Sub}}=\frac{\sum_{\mathrm{i}=1}^{\mathrm{n}} \mathrm{I}_{\mathrm{i}}}{\mathrm{n}}
$$

In which, $\mathrm{I}_{\mathrm{Sub}}$ is the sub-index of the indicator group, $\mathrm{I}_{\mathrm{i}}$ is the standardized environmental protection activity index of the secondary directive $i$.

Combining the sub-index into the overall index of environmental protection performance

The EPIIP index was combined from the sub-indexes of the subjects according to the formula as $I_{L S X}=\sum_{j}^{n} w_{j} I_{S u b j} \times 100$

$\mathrm{I}_{\mathrm{LSX}}$ is the environment performance index EPIIP, $\mathrm{W}_{\mathrm{j}}$ is the weight of indicator group $\mathrm{j}$ th, $\mathrm{I}_{\text {Subj }}$ is the sub-index of EPIIP $\mathrm{j}^{\text {th }}$. The range level of EPIIP from 0 to 100.

TABLE 3. The proposed scale of the EPIIP

\begin{tabular}{rll}
\hline Scale & & Level \\
\hline $1-20$ & Very bad \\
$20-40$ & Bad \\
$40-60$ & medium \\
$60-80$ & Relatively good \\
$80-100$ & Good \\
\hline
\end{tabular}

\section{Results}

\section{Building the indicator system for evaluating environmental performance in industrial parks}

The indicator set was established based on the DPSIR model such as drivers - D (socioeconomic development, the underlying cause of environmental changes); Pressure - P (direct sources of pollution and environmental degradation); $\mathrm{S}$ - the state of the 
environment is affected; Impact - I (impact of environmental pollution on public health, socio-economic development and ecological environment activities); Response - R (environmental protection solutions) (Rainer Brüggemann \& Ganapati P Patil, 2011). The indicator set used to evaluate environmental protection activities in the industrial park includes 18 subjects and 35 indicators, specifically as follows:

$T A B L E 4$. The indicators of the EPIIP

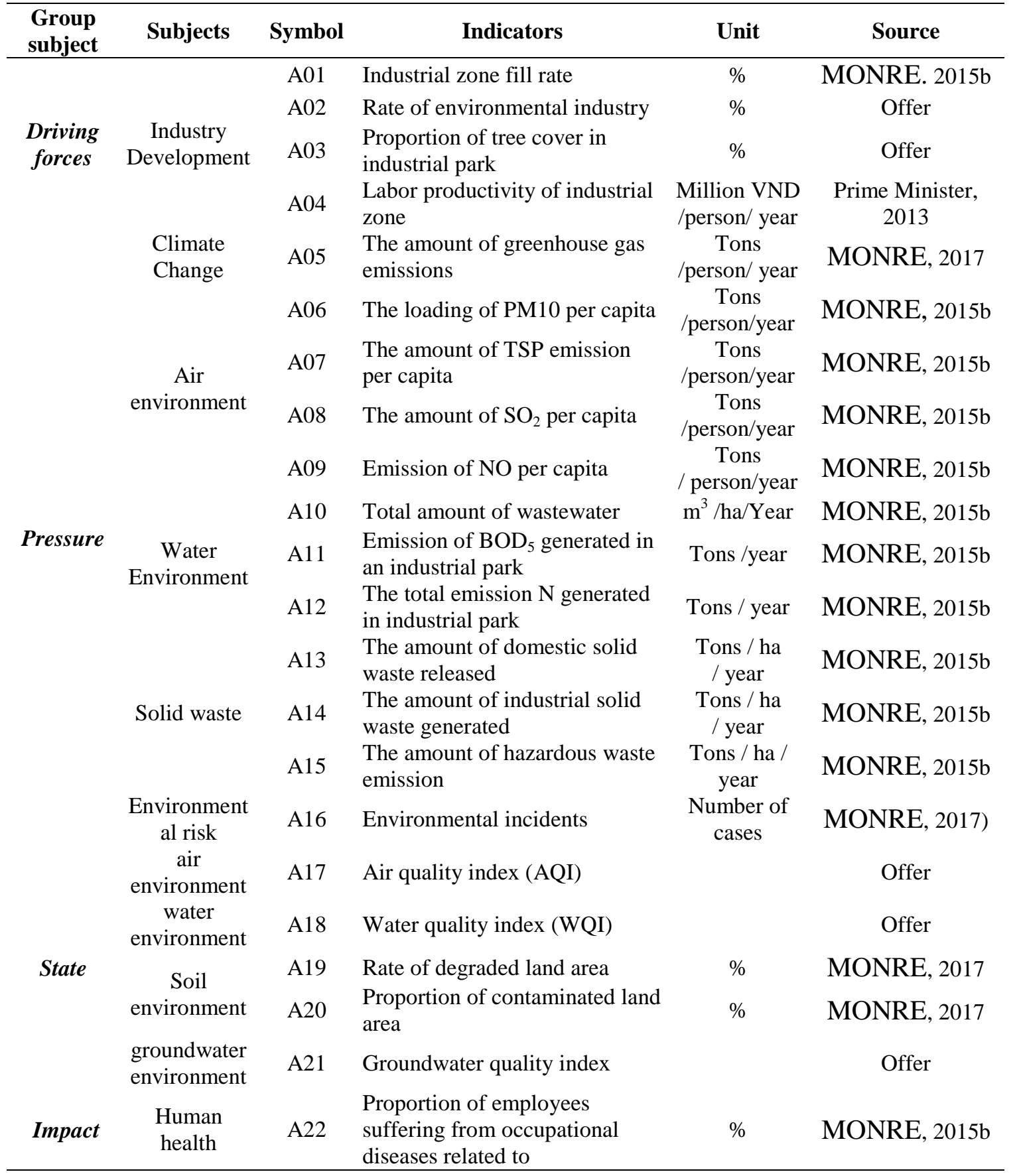




\begin{tabular}{|c|c|c|c|c|c|}
\hline & & & $\begin{array}{l}\text { environmental pollution in the } \\
\text { enterprises }\end{array}$ & & \\
\hline & & A23 & $\begin{array}{l}\text { Percentage of people with } \\
\text { respiratory disease in polluted } \\
\text { areas }\end{array}$ & $\%$ & MONRE, 2015b \\
\hline & $\begin{array}{l}\text { Environment } \\
\text { al impact }\end{array}$ & A24 & $\begin{array}{l}\text { Rate of facilities causing } \\
\text { environmental pollution were } \\
\text { discovered during the year }\end{array}$ & $\%$ & MONRE, 2017 \\
\hline & & A25 & $\begin{array}{l}\text { Proportion of budget } \\
\text { expenditure for environmental } \\
\text { protection activities }\end{array}$ & $\%$ & MONRE, 2017 \\
\hline & $\begin{array}{l}\text { Environment } \\
\text { al pollution }\end{array}$ & A26 & $\begin{array}{l}\text { The rate of establishments } \\
\text { causing environmental pollution } \\
\text { is overcome }\end{array}$ & $\%$ & MONRE, 2015b \\
\hline & & A27 & $\begin{array}{l}\text { Proportion of business meet } \\
\text { environmental standards or are } \\
\text { certified with ISO } 14001 \text { or } \\
\text { applied clean technology }\end{array}$ & $\%$ & $\begin{array}{c}\text { MONRE, 2015b, } \\
2017\end{array}$ \\
\hline & $\begin{array}{l}\text { Wastewater } \\
\text { control }\end{array}$ & A28 & $\begin{array}{l}\text { Rate of production, business } \\
\text { and service establishments } \\
\text { generating wastewater of more } \\
\text { than } 50 \mathrm{~m}^{3} / \text { day have wastewater } \\
\text { treatment systems to comply }\end{array}$ & $\%$ & MONRE, 2015b \\
\hline Response & & & $\begin{array}{l}\text { with national technical } \\
\text { regulations }\end{array}$ & & \\
\hline & $\begin{array}{l}\text { Emission } \\
\text { control }\end{array}$ & A29 & $\begin{array}{l}\text { Percentage of enterprises have } \\
\text { air waste treatment systems }\end{array}$ & $\%$ & Offer \\
\hline & Safety and & A30 & $\begin{array}{l}\text { Percentage of establishments } \\
\text { with fire protection certification }\end{array}$ & $\%$ & Offer \\
\hline & health & A31 & $\begin{array}{l}\text { The number of environmental } \\
\text { staff per } 100 \text { enterprises }\end{array}$ & $\begin{array}{l}\text { People / } \\
\text { enterprises }\end{array}$ & MONRE, 2017 \\
\hline & Clean energy & A32 & $\begin{array}{l}\text { Rate of renewable energy } \\
\text { sources used }\end{array}$ & $\%$ & MONRE, 2015b \\
\hline & & A33 & $\begin{array}{l}\text { Rate of collecting domestic } \\
\text { solid waste }\end{array}$ & $\%$ & MONRE, 2015b \\
\hline & $\begin{array}{l}\text { Solid waste } \\
\text { management }\end{array}$ & A34 & $\begin{array}{l}\text { Rate of gathering industrial } \\
\text { solid waste }\end{array}$ & $\%$ & MONRE, 2015b \\
\hline & & A35 & $\begin{array}{l}\text { Rate of hazardous waste is } \\
\text { collected and treatment }\end{array}$ & $\%$ & MONRE, 2017 \\
\hline
\end{tabular}

Determining weight of indicators and subjects for the EPIIP

TABLE 5.The weight of the subjects of the EPIIP

\begin{tabular}{|c|c|l|c|}
\hline $\begin{array}{c}\text { subject } \\
\text { group }\end{array}$ & Weight subject & \multicolumn{1}{|c|}{ Subjects } & $\begin{array}{c}\text { Weight } \\
\text { subjects }\end{array}$ \\
\hline Driving & 0.072 & Industry Development & 0.072 \\
\hline \multirow{3}{*}{ Pressure } & \multirow{3}{*}{0.129} & Air environment & 0.283 \\
\cline { 3 - 4 } & & Water Environment & $\mathbf{0 . 3 9 6}$ \\
\cline { 3 - 4 } & & Solid waste & 0.108 \\
\cline { 3 - 4 } & & Environmental risk & 0.118 \\
\hline
\end{tabular}


Thu Dau Mot University Journal of Science - Volume 2 - Issue 3-2020

\begin{tabular}{|c|c|l|c|} 
& & Climate Change & 0.094 \\
\hline \multirow{3}{*}{ State } & \multirow{3}{*}{0.243} & Air environment & 0.302 \\
\cline { 3 - 4 } & & Water environment & 0.386 \\
\cline { 3 - 4 } & & Soil environment & 0.175 \\
\cline { 3 - 4 } & \multirow{3}{*}{ Impact } & Underground water environment & 0.137 \\
\hline \multirow{3}{*}{ Response } & \multirow{3}{*}{0.157} & human health & 0.078 \\
\cline { 3 - 4 } & & Environmental impact & 0.078 \\
\hline \multirow{2}{*}{0.399} & Environmental pollution management & 0.098 \\
\cline { 3 - 4 } & & Wastewater control & 0.325 \\
\cline { 3 - 4 } & & Emission control & 0.241 \\
\cline { 3 - 4 } & & Safety and health & 0.105 \\
\cline { 3 - 4 } & & Clean energy & $\mathbf{0 . 0 5 9}$ \\
\cline { 3 - 4 } & & Solid waste management & 0.171 \\
\hline
\end{tabular}

\section{The results of Standardized indicators}

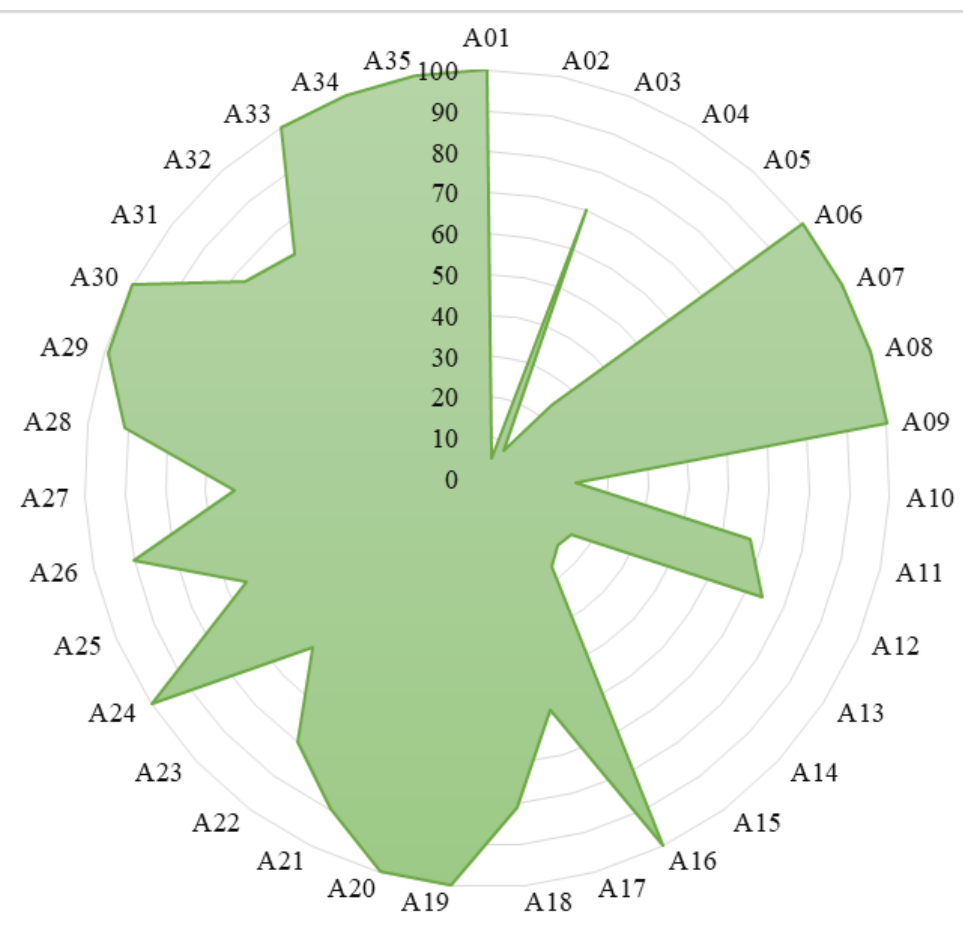

Figure 2. The standardized indicators of the EPIIP in VSIP I industrial park

The result of standardized indicator A24 (Rate of facilities causing serious environmental pollution) was $0 \%$, showing that the environmental management was quite good in industrial zone VSIP I 
Besides, the results also showed that the indicator A02 (Rate of environmental industry) is the lowest value of $0.05 \%$. It indicated that the environmental industry had not been invested and paid adequate attention in industrial park VSIP and had the lowest impact on environmental protection activities in there.

The range of indicators from A06 to A09, A19, and A20 (in the negative group) have the highest standardized values showing the influence of these indicators on environmental protection activities in industrial park VSIP.

The indicators from A33 toA35 (positive group) were the highest standardized scale, showing that the environmental management activities of industrial park VSIP I was a great influence on environmental protection activities.

The environmental performance index of industrial parks in the VSIP I, Binh Duong, Vietnam

Among the subject groups on environmental protection activities in the industrial areas, the topic of response were the highest level that indicated the environment played important role of the VSIP I Industrial Park to environmental management and protection issues. In fact, VSIP I Industrial Park was the earliest representative industry in Binh Duong province. With 100\% of the land occupied, VSIP I has now attracted 231 projects with a total investment of about 3.2 billion USD. The project has created 95,000 jobs for workers and contributed to the industrialization, modernization and urbanization of Binh Duong province. Environmental management and pollution control in VSIP I have been carried out closely, in collaboration with the competent agencies and local environmental management agencies as well as the Central Government.

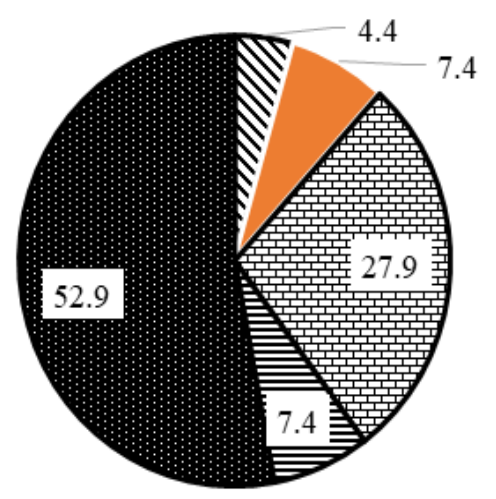

$\boldsymbol{\Delta}$ drivers - pressures $\mathbf{0}$ state $\boldsymbol{\theta}$ impact response

Figure 3. The sub-index of the EPIIP 
Driving force subject group was little impact on environmental protection activities in industrial park. Thereby, it is shown that in order to have a better environment in the Industrial Park, the investment mechanisms, policies and business orientations in term of the environment were a greater influence than the promotion of the industrial zone's economic development.

\section{Discussion}

The environmental performance index of industrial park was an effective tool to assess the status of environmental protection activities in industrial zones. The indicator system was generally described by clear and easy-to-understand which improved environmental protection activities.

The environmental performance index of industrial park of VSIP I was 68,95 point (relatively good level) that pointed out the VSIP I carried out a range of measures to protect the environment. The environmental state and pollution control in VSIP I Industrial Park implemented a good practice.

\section{Acknowledgments}

This work was supported foundation by Thu Dau Mot University. We were thanked to Binh Duong Department of Natural Resources and Environment and VSIP I Industrial Zones Authority providing data for this study.

\section{References}

U.S. Environmental Protection Agency (2014). Creating an overall environmental quality index. Chapel Hill, North Carolina.

Rainer Brüggemann, \& Ganapati P Patil (2011). Ranking and prioritization for multi-indicator systems: Introduction to partial order applications (Vol. 1): Springer Science \& Business Media.

Ministry of Construction (2018). Regulation on green growth urban construction targets. Circular No. 01/2018 / TT-BXD

Daniel C. Esty, Tanja Srebotnjak, Christine H. Kim, Marc A. Levy, Alexander de Sherbinin, \& Bridget Anderson. (2006). Pilot 2006 Environmental Performance Index (EPI): Yale University, Columbia University.

Roveda. José Arnaldo Frutuoso, Maurício Tavares Mota, Sandra Regina Monteiro Masalskiene Roveda, Roberto Wagner Lourenço, \& Antonio César Germano Martins. (2010). Fuzzy environmental quality index.

Prime Minister (2013). Promulgating set of monitoring and evaluation indicators for local sustainable development in the period of 2013-2020. Decision No. 2157/QD-TTg. 
Institute for Financial Management and Research. (2010). Environmental Sustainability Index for Indian States 2009. Chennai: Institute for Financial Management and Research.

Ministry of Natural Resources and Environment - MONRE (2015a). Regarding environmental protection of economic zones, industrial parks, export processing zones and hi-tech parks. Circular No. 35/2015/TT-BTNMT.

Ministry of Natural Resources and Environment (2015b). Regarding environmental status report, environmental indicators system and environmental monitoring data management. Circular No. 43/2015/TT-BTNMT.

Ministry of Natural Resources and Environment (2017). Promulgating the statistical indicator system for natural resources and environment . Circular No. 73/2017/TT-BTNMT.

Ministry of Natural Resources and Environment (2019). Issued a set of indicators for evaluating environmental protection results of central provinces and cities. Decision No. 2782/2019/QD-BTNMT.

Yale Center for Environmental Law and Policy, \& Center for International Earth Science Information Network. (2005). 2005 Environmental sustainability index Retrieved 11/11, 2011, from <http://www.yale.edu/esi/ESI2005_Main_Report.pdf>. 